\title{
Early Identification of At-Risk Infants and Toddlers: A Transdisciplinary Model of Service Delivery
}

\author{
Legini Moodley, Brenda Louw and René Hugo
}

Department of Communication Pathology

University of Pretoria

\begin{abstract}
Traditional models of service delivery prevent speech-language therapists and audiologists from identifying and implementing early communication intervention (ECI) in South Africa. This study utilized the framework of the transdisciplinary team approach to develop a collaborative partnership between community nurses and speech-language therapists and audiologists. An interdisciplinary in-service training programme was implemented with 24 community nurses employed at family health clinics in Kwa-Zulu Natal; with the aim of enhancing their knowledge and attitudes toward the early identification and referral of at-risk children to speech-language therapists and audiologists. Three questionnaires were used to evaluate the nurses' knowledge and attitudes. Results indicated that the training programme significantly improved the nurses' knowledge regarding ECI but not their attitudes. Implications of these findings are discussed in terms of service delivery for ECI, and the education and training of early interventionists in the South African context.
\end{abstract}

KEY WORDS: early communication intervention, infants and toddlers, at-risk, transdisciplinary team model, interdisciplinary in-service training.

\section{INTRODUCTION}

Early identification of at-risk infants and toddlers is the first crucial step in Early Communication Intervention (ECI), and it has a significant impact on treatment efficacy. A factor that is consistently linked to the efficacy of early 'intervention services is that of age of identification (Rossetti, 1993; 1996). Improving age of identification by implementing methods of service delivery that promote earlier detection of children who are at-risk for developing communication disorders is important for effective management, and constitutes an important goal of speechlanguage therapists and audiologists. However, gaining earlier access to infants and toddlers and their families in need of ECI appears to be an international and national challenge confronting speech-language therapists and audiologists.

Despite research evidence to support early intervention, specifically ECI, many children with communication disorders are not referred to speech-language therapists and audiologists as the prevailing attitude of many health professionals continues to be "wait and see as the child may outgrow it" (Rossetti, 1996; Louw \& Kritzinger, 1991). This attitude reflects the need for greater consultation and collaboration between speech-language therapists and audiologists and referring health care professionals to promote greater awareness of speech, language and audiological services.

Delayed communication development is identified as the most common symptom of developmental disability in children under three years of age, affecting approximately $5 \%$ to $10 \%$ of that population (Rossetti, 1996). In South Africa, it is estimated that children under the age of four years comprise 5 million of the country's 38 million population (A National Health Plan for South Africa, 1994; Central Statistical Services, personal communication, July 2,1998 ). Using Rossetti's (1996) estimates, which are relevant for a developing country, South Africa could expect approximately 250000 to 500000 children to present with delayed communication development.

The prevalence of developmental delays and disabilities in children under three years of age is rapidly increasing due to advances in life-saving medical technology and new and expanding populations of infants and toddlers (Rossetti, 1996). In developing countries like South Africa, at-risk children and their families face additional political, social, cultural, economic, linguistic, and environmental conditions that place them at increased risk for developmental disabilities (Pickering et al., 1998). The White Paper on Integrated National Disability Strategy (1997) indicates that $80 \%$ of black children with disabilities live in extreme poverty in inhospitable environments. The implication for speech-language therapists and audiologists is evident: early identification of communication disorders in infants and toddlers (0-3years), and the timely provision of early communication intervention (ECI) is vital to enhance the overall developmental potential of these children.

There are currently only 1750 registered speechlanguage therapists and audiologists (Y. Hoffman, Health 
Professions Council of South Africa, personal communication, 21 August 2000) to cater for the country's approximately 3,8 million people who require communication treatment (Pickering et al., 1998). However, a very small number of these professionals are adequately trained in ECI (Fair \& Louw, 1999).

Besides the shortage of qualified personnel, speechlanguage therapists and audiologists' use of traditional institution-based models of service delivery have proven to be ineffective in reaching the majority of the vulnerable and disadvantaged communities of South Africa. The restructured National Health System mandates a transition in service delivery from institution-based services to community-based services (White Paper on Integrated National Disability Strategy, 1997).

The South African government has adopted the Primary Health Care (PHC) approach as the underlying philosophy for the restructuring of its health system (Department of Health, 1995). However, besides legislating free health care services for all children under six years of age, specific policies for the disabled and at-risk population are lacking (White Paper on Integrated National Disability Strategy, 1997; Fair \& Louw, 1999).

The principles underlying South Africa's National Health System provide strong support for the implementation of recommended ECI practices. ASHA (1989) identified four quality indicators for effective ECI services to the at-risk population, namely; services need to be family-centred, community-based, comprehensive, and co-ordinated. Moreover, research has identified the team model of service delivery as being critical for the provision of comprehensive and coordinated ECI services (ASHA, 1989; Fair \& Louw, 1999).

The transdisciplinary team model of service delivery is currently viewed as the preferred model of practice in early intervention (Briggs, 1997). It is an integrative service delivery model that is characterized by three operational principles, namely; role release, role expansion, and arena evaluation as it requires professionals across disciplines to pool and exchange information, knowledge, and skills by crossing and re-crossing traditional boundaries. The latter principles provide a mechanism for the delivery of community-based, family-centered, comprehensive and coordinated ECI services to at-risk infants and toddlers.

The transdisciplinary model is ideal for the diverse South African context as it supports the PHC and community-based models of service delivery. Speech-language therapists and audiologists practice at the tertiary level of health care, whilst the at-risk population is present at the primary level. The adoption of the transdisciplinary principles will allow speechlanguage therapists and audiologists to establish partnerships with referring health professionals (based at the primary level of health care), thereby facilitating access to infants and toddlers who are at-risk for developing communication disorders (Fair \& Louw, 1999). Moreover, ASHA (1991) states that the transdisciplinary model is especially suited to service contexts where the demand is incongruous with the services provided because of the shortage of qualified staff, and when economic and other factors restrict service provision.

In light of the current South African context and the suitability of the transdisciplinary team model for ECI, this model of service delivery was selected to enable South African speech-language therapists and audiologists to gain earlier access to children at-risk for developing communication disorders. For this study, community nurses employed at community-based family health clinics were selected as the health professionals with whom speech-language therapists and audiologists could consult and collaborate.

Community-based primary health care nurses are the frontline health professionals in the early intervention team as they have direct contact with at-risk children, and are based at family health clinics that are accessible and affordable to the majority of the South African population. More importantly, in contrast to the current 1750 registered speech-language therapists and audiologists, there are approximately 21.000 qualified community nurses (National Health Plan, 1994). In addition, infants receive developmental screening at family health clinics from six weeks of age, thus presenting the ideal context for the monitoring of early communication development.

Effective collaborative partnerships require both partners to share a common philosophy about the outcome of their services (Briggs, 1997); and to possess a specialized core of knowledge and skills for working with at-risk infants, toddlers and their families (Roberts, Crais, Layton, Watson, \& Reinhartsen, 1995). However, current research findings indicate that many health professionals do not possess this common philosophy or specialized knowledge and skills (Weitzner-Lin, Chambers \& Siepierski, 1994; Delport, 1998).

One of the ways to ensure that community nurses possess the necessary attitudes and knowledge to identify and appropriately refer children at-risk for communication disorders, is for the speech-language therapist and audiologist to serve as a source of information and provide relevant in-service training programmes to community nurses (Rossetti, 1993; Delport, 1998). Although the transdisciplinary team approach provides the infrastructure to promote mutual teaching and learning, it does not facilitate the process of education and training, thus necessitating the adoption of an interdisciplinary model of education and training. Interdisciplinary education refers to the collaboration of two or more disciplines in the learning process (American Association of Colleges of Nursing, 1996), and is identified as the recommended practice for the education and training of early interventionists (Briggs, 1997).

To facilitate the training process and the identification of community nurses' specialized knowledge and attitudes for ECI, a model of the role of community nurses in ECI was developed. This model identified the primary roles of community nurses in ECI as being: screening, identification, referral and monitoring of at-risk children. Based on these roles, the theoretical framework proposed by Hanson and Brekken (1991) was utilized to identify the nurses' specialized knowledge and attitudes for ECI. This framework stipulates that early interventionists' specialized attitude and knowledge base is developed from two levels: (1) a set of professional discipline-specific knowledge and attitudes; and (2) a common early intervention knowledge and attitude base. Figure 1 illustrates the development of the three levels of knowledge from discipline specific to specialized.

However, will an interdisciplinary in-service training programme influence 'community nurses' knowledge and attitudes regarding $E C I$, so that it promotes their ability to identify and refer children who are at-risk for communication disorders? This is the research question that formed the basis for the present study. According to Briggs (1997) training programmes provide high quality, low-cost and easily accessible opportunities for professionals to master new service delivery roles; while also ensuring that infants, toddlers, and their families have appropriate and effective 
ECI services. The provision of training programmes in ECI by speech-language therapists and audiologists to community nurses, is poorly documented in the literature (Delport, 1998). Consequently, the aim of this study is to determine whether an in-service training programme for community nurses will influence their knowledge and attitudes with respect to the early identification of at-risk children.

\section{METHOD}

\section{$A I M$}

The purpose of this study was to determine whether an inservice training programme for community nurses employed at family health clinics influenced their knowledge and attitudes with respect to the early identification of infants and toddlers (0-3 years) who were at-risk for developing communication disorders. The following objectives were formulated:

- Determination of community nurses' present knowledge and attitudes with regard to the early identification of infants and toddlers (0-3 years) who are at-risk for developing communication disorders.
- Development and implementation of an in-service training programme to enhance community nurses' knowledge and attitudes with regard to the early identification of infants and toddlers (0-3 years) who are at-risk for developing communication disorders

- Determination of the effect of the in-service training programme on community nurses' knowledge and attitudes with regard to the early identification of infants and toddlers ( $0-3$ years) who are at-risk for developing communication disorders.

\section{RESEARCH DESIGN}

An exploratory descriptive survey - quasi-experimental time series design was utilized (Rosnow \& Rosenthal, 1996). This design involved utilizing the survey method to obtain a measure of the knowledge and attitudes of community nurses with regard to ECI. This evaluation was then followed by the implementation of an in-service training programme. Thereafter, the survey method was utilized again to obtain two further measures of the nurses' knowledge and attitudes following the training programme, one immediately after the training programme and the second 6 weeks later.

\section{Specialized Knowledge and Attitude for Early Communication Intervention level 3}

KNOWLEDGE: * Specific risk factors for cormumication disorders * Importanœ of communication domain in relation to other developmental domains * Concept of continum of risk * Role of speech-language therapist and audiologist * Screening assessment of infant and toddlers' communication skills * Criteria for identifying the presence or absence of a communication disability * Speech-language therapy and audiology resources in the community * Basic communicationbased intervention

ATTITUDE: A positive attitude towards the importance of communication skills for overall development, and the need for early referral to the speech-language therapist and audiologist.

\section{Common Knowledge and Attitude regarding Early Intervention} level 2

KNOWLEDGE: * Legislation on early intervention (international and national directives) * Efficacy of early intervention * Epidemiologic overview of the at-risk infant and toddler population * Team model of service delivery, with specific reference to the transdisciplinary team approach

ATTITUDE: A positive attitude towards early intervention, its' effectiveness, and the benefit of the transdisciplinary team model of service delivery.

\section{Discipline-Specific Knowledge and Attitude for Early Communication Intervention}

\section{level 1}

KNOWLEDGE: * Normal infant development * Atypical infant development * Family dynamies and assessment * Planning implementing and evaluating an intervention plan * Community's medical, social and financial resources ATTITUDE: A positive attitude towards the management of infants, toddlers and their families.

FIGURE 1: The three levels of knowledge that community nurses require for practice in early communication intervention. (Conceptualized from Hanson \& Brekken, 1991; Rossetti, 1996; Brandt \& Magyary, 1989; and Cox, 1996). 


\section{SURJECTS}

The target population for this study was community nurses employed at family health clinics, which are situated in the Durban Functional Region of Kwa Zulu Natal. The subjects were required to meet the following criteria. Community nurses needed to be registered with the South African Nursing Council to ensure that they had a valid qualification in nursing, since the study focused on their knowledge and attitudes with regard to ECI. They also needed to be currently employed at family health clinics, and involved in the practice of developmental monitoring of infants and toddlers as their knowledge and attitudes in this area was the focus of the study.

\section{Selection of Community Nurses}

Nonprobability convenience sampling was utilized (Leedy, 1993), which entailed the researcher working with those community nurses who were selected by the nursing administrators. Therefore, this method of sampling made no pretence of being representative of the population; and did not attempt to control for bias (Leedy, 1993). Logistical constraints imposed by the need to maintain service delivery at the clinics, allowed only 30 of the total 127 community nurses to participate in the study

\section{Description of the Community Nurses in the Study}

On the day of data collection, only 24 community nurses participated in the training programme, representing $19 \%$ of the total population. All the nurses in the sample completed and returned the pre-training and post-training 1 survey (i.e. Questionnaires 1 and 2), thereby representing a $100 \%$ response rate. However, only 21 of the 24 nurses completed and returned the post-training 2 survey (i.e, Questionnaire 3). The response rate for Questionnaire 3 was therefore $88 \%$.

Table 1 provides the biographical characteristics of the subjects who participated in the pre-training and two posttraining surveys of the study.

TABLE 1: Biographical characteristics of the community nurses who participated in the three surveys

\begin{tabular}{|c|c|c|c|c|}
\hline Characteristics & $\begin{array}{l}\text { Pre-Training } \\
\text { Survey and } \\
\text { Post-Training } \\
\text { Survey } 1 \\
\text { n=24 }\end{array}$ & $\begin{array}{l}\text { Pre-Training } \\
\text { Survey and } \\
\text { Post-Training } \\
\text { Survey } 1 \\
\%\end{array}$ & $\begin{array}{l}\text { Post-Training } \\
\text { Survey } 2 \\
\mathrm{~N}=21\end{array}$ & $\begin{array}{c}\text { Post-Training } \\
\text { Survey } 2 \\
\%\end{array}$ \\
\hline $\begin{array}{l}\text { Work Environment } \\
\text { - Family Health Clinic }\end{array}$ & 24 & $100 \%$ & 21 & $100 \%$ \\
\hline $\begin{array}{l}\text { Geographic Area } \\
\text { - Durban Functional Region }\end{array}$ & 24 & $100 \%$ & 21 & $100 \%$ \\
\hline $\begin{array}{l}\text { Professional Qualification } \\
\text { - Degree } \\
\text { - } \quad \text { Diploma }\end{array}$ & $\begin{array}{c}5 \\
19\end{array}$ & $\begin{array}{l}21 \% \\
79 \%\end{array}$ & $\begin{array}{c}3 \\
18\end{array}$ & $\begin{array}{l}14 \% \\
86 \%\end{array}$ \\
\hline $\begin{array}{l}\text { Community Nursing Qualification } \\
-\quad \text { Yes } \\
-\quad \text { No }\end{array}$ & $\begin{array}{c}23 \\
1\end{array}$ & $\begin{array}{l}96 \% \\
4 \%\end{array}$ & $\begin{array}{c}20 \\
1\end{array}$ & $\begin{array}{l}95 \% \\
5 \%\end{array}$ \\
\hline $\begin{array}{l}\text { Employment Status } \\
-\quad \text { Permanent } \\
-\quad \text { Full-Time }\end{array}$ & $\begin{array}{l}24 \\
24\end{array}$ & $\begin{array}{l}100 \% \\
100 \%\end{array}$ & $\begin{array}{l}21 \\
21\end{array}$ & $\begin{array}{l}100 \% \\
100 \%\end{array}$ \\
\hline $\begin{array}{l}\text { Experience at Family Health Clinics } \\
-\quad 0-5 \text { years } \\
-\quad 6-10 \text { years } \\
-\quad 11-15 \text { years } \\
-\quad 16-20 \text { years } \\
-\quad>20 \text { years }\end{array}$ & $\begin{array}{l}14 \\
6 \\
1 \\
2 \\
1\end{array}$ & $\begin{array}{l}58 \% \\
25 \% \\
4 \% \\
8 \% \\
4 \%\end{array}$ & $\begin{array}{l}12 \\
6 \\
1 \\
2 \\
0\end{array}$ & $\begin{array}{c}57 \% \\
29 \% \\
5 \% \\
10 \% \\
00 \%\end{array}$ \\
\hline $\begin{array}{l}\text { Attendance at early communication } \\
\text { intervention workshop/training } \\
\text { - programme } \\
\text { - Yes } \\
\text { - No }\end{array}$ & $\begin{array}{c}0 \\
24\end{array}$ & $\begin{array}{l}0 \% \\
100 \%\end{array}$ & $\begin{array}{c}21 \\
0\end{array}$ & $\begin{array}{l}100 \% \\
0 \%\end{array}$ \\
\hline $\begin{array}{l}\text { First Language } \\
-\quad \text { English } \\
-\quad \text { Zulu }\end{array}$ & $\begin{array}{c}16 \\
8\end{array}$ & $\begin{array}{l}67 \% \\
33 \%\end{array}$ & $\begin{array}{c}15 \\
6\end{array}$ & $\begin{array}{l}76 \% \\
4 \%\end{array}$ \\
\hline
\end{tabular}




\section{MATERIALS AND APPARATUS}

Three questionnaires and an in-service training programme were the main materials and apparatus that were utilized in the study. Self-administered questionnaires were used as they facilitated the observation of the nurses' knowledge and attitudes regarding ECI, which were beyond the physical reach of the researcher (Leedy, 1993). Questionnaire 1 was utilized in the pre-training survey, Questionnaire 2 was utilized in the post-training 1 survey, while Questionnaire 3 was utilized in the post-training 2 survey, as reflected in Figure 2.

\section{The Design and Development of the Questionnaires}

Guidelines provided by Brink (1996); Rosnow and Rosenthal (1996) and Leedy (1993) were used to develop the questionnaires. The questionnaires comprised four main sections, with an additional section included in questionnaires 2 and 3 , which focused specifically on the nurses' evaluation of the training programme. The four sections were: (a) biographical information; (b) discipline specific knowledge for ECI; (c) common knowledge and attitudes for early intervention; and (d) specialized knowledge and attitudes for ECI. [Refer to Tables 1, 3, 4, 5, and 6 for information regarding questions included in each section]. All questions, except the last one, were constructed using the structured closed-ended format, in order to accommodate for the time constraints of the nurses. The questionnaires contained content that was relevant for community nurses to know, in order to implement their roles of screening, identifying, referring and monitoring children who are atrisk for communication. [For detailed motivations regarding the questions that were included in the three questionnaires, the reader is referred to the original study by Moodley, 1999].

\section{Reliability and Validity of the Questionnaires}

Reliability was ensured by paying careful attention to the formulation, length and complexity of questions; pilottesting the questionnaire; coding of data; and qualitatively analyzing the items in the questionnaire by providing an estimate of the internal consistency of the instrument (Brink, 1996). A thorough and extensive review of the literature ensured that only relevant items were included. Some of the questions were based on the questionnaire utilized by Louw \& Weber (1997), and to ensure content validity, the questionnaires were approved by two South African experts in the field of ECI.

\section{Design and Development of the In-Service Training Programme}

The training programme was designed to accommodate the restrictions placed by Durban City Health Department regarding minimal disruptions in service delivery. Consequently, it was planned to be two hours in duration and to occur over two afternoons (1 hour per afternoon). Table 2 presents a description of the development of the training programme.

TABLE 2: Development of the training programme

\begin{tabular}{|c|c|}
\hline FACTORS & USE IN TRAINING PROGRAMME \\
\hline Aims & $\begin{array}{l}\text { - To enhance community nurses' knowledge in ECI } \\
\text { - To foster community nurses' development of positive attitudes towards ECI }\end{array}$ \\
\hline Philosophy & $\begin{array}{l}\text { To promote a community-based, family-centred, comprehensive and co-ordinated } \\
\text { philosophy towards the rendering of ECI services to at-risk infants and toddlers } \\
\text { (ASHA, 1989). }\end{array}$ \\
\hline Structure & $\begin{array}{l}\text { - An outcomes-based approach was utilized as Hugo (1996) states that training that } \\
\text { is based on outcomes provides a logical correlation between education and } \\
\text { professional practice. Accordingly, the guidelines of the National Qualifications } \\
\text { Framework were used to develop specific outcomes; and information by Bennet, } \\
\text { Watson \& Raab (1995) were used to develop a training plan (Refer to Figure 2) }\end{array}$ \\
\hline Implementation Process & $\begin{array}{l}\text { - The following five factors informed the implementation process: } \\
\text { - a systems approach to change was adopted in order to effect longterm practice changes } \\
\text { (Briggs, 1997). } \\
\text { - a preliminary needs analysis was conducted to ensure that training was responsive } \\
\text { to the perceived needs of the nurses (Winton, 1996). } \\
\text { - an empowerment perspective was adopted to create the necessary conditions for } \\
\text { change (Trivette, Dunst, Hamby \& LaPointe, 1996). } \\
\text { - a choice of instructional strategies were utilized that supported the principles of } \\
\text { adult learning, for example, participant choice and responsibility for own learning } \\
\text { (Winton, 1996). } \\
\text { - follow-up support was provided to ensure application of learning (Winton, 1996) }\end{array}$ \\
\hline Training Environment & - The training offices of the Durban City Health Department. \\
\hline Evaluation Strategy & $\begin{array}{l}\text { - Analysis of the nurses' responses on the pre-training questionnaire (Questionnaire } \\
\text { 1) and the two post-training questionnaires (Questionnaires } 2 \text { and } 3 \text { ). }\end{array}$ \\
\hline
\end{tabular}

KEY: ECI = Early Communication Intervention 
Validity and Reliability of the In-Service Training Programme

Content validity was established by presenting the plan of the training programme to two expert early interventionists with experience in the use of training programmes, as well as the nursing administrators for their critical review (Rosnow \& Rosenthal, 1996). Since the training programme was implemented over two afternoons, every effort was made to ensure that similar conditions prevailed during the implementation process for both sessions. Trainer bias was controlled for by adherence to a strict training protocol (Rosnow \& Rosenthal, 1996). In addition, a pilot study of the programme was conducted.

\section{PILOT STUDIES ON THE QUESTIONNAIRES AND IN-SERVICE TRAINING PROGRAMME}

Pilot studies of the three questionnaires and the training programme were conducted to increase the accuracy and reliability of the data. Four community nurses, who were not part of the main study, were selected according to the criteria stipulated earlier. On the basis of the pilot studies the questionnaires and training programme were adapted.

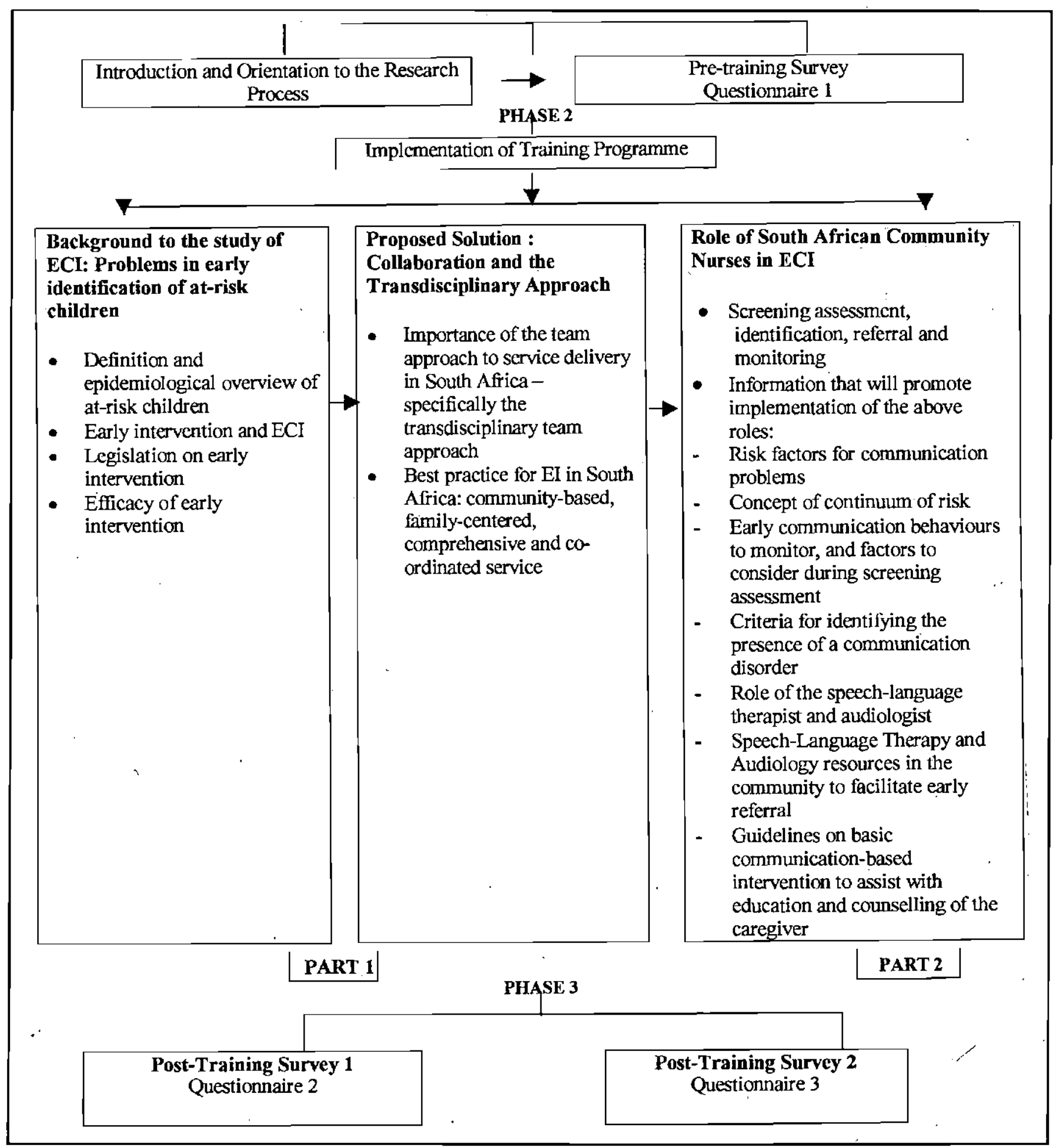

FIGURE 2: An illustration of the implementation of the main study 


\section{THE MAIN STUDY}

The main study was conducted over three phases, namely; the pre-training survey, implementation of the inservice training programme, and the post-training surveys. Figure 2 illustrates the processes of the three phases as they occurred.

During the introduction the trainer did not indicate her professional background, nor was any information regarding early intervention or ECI presented at this stage so as not to influence the nurses responses on the pre-training survey. The pre-training survey occurred first and the trainer was present to answer queries thereby preventing misunderstandings from biasing the data (Brink, 1996).

The training programme commenced immediately after Questionnaire 1 was collected. Part 1 of the training programme commenced on the first afternoon with a brief discussion of the background to the study of ECI, and ended with the proposed solution of the transdisciplinary approach (refer to Figure 2). Part 2 of the training programme continued the next afternoon and focussed on the role of South African community nurses in ECI. A handout on ECI, prepared on the basis of the training plan, was distributed to the nurses at the start of the programme to facilitate the learning process. At the end of Part 1 of the training programme, the nurses were allowed to take the handout with them and were encouraged to read it.

Immediately after Part 2 of the training programme ended, Questionnaire 2 was distributed and collected. Six weeks after the training programme, Questionnaire 3 was given to the nursing administrators, for distribution to the participants of the training programme, and the completed questionnaires were collected from the nursing administrators.

\section{DATA ANALYSIS}

Descriptive and inferential statistical methods were employed. Data were analysed using the statistics computer software called Statistical Package for the Social Sciences (SPSS) [Leedy, 1993]. Descriptive statistics, which included frequency counts, percentages, and measures of central tendency and variance, were used to describe and summarise the data (Rosnow \& Rosenthal, 1996). Inferential statistics, namely; the parametric one-way Analysis of Variance (ANOVA) [Rosnow \& Rosenthal, 1996] was utilized to determine whether any differences found among the three evaluations, were real differences that may be attributed to the influence of the training programmes. When a statistically significant difference was obtained, post-hoc comparison tests utilizing the Bonferroni test, were calculated to determine which of the means differed significantly (Brink, 1996). Thematic analysis was utilized to analyse the open-ended questions.

\section{RESULTS AND DISCUSSION}

The results are discussed in accordance with the main aim of the study. The findings for objectives one and three are presented concurrently to highlight any similarities and differences that may exist among the three measures.

\section{INFLUENCE OF THE IN-SERVICE TRAINING PROGRAMME ON COMMUNITY NURSES' KNOW- LEDGE AND ATTITUDES WITH REGARD TO EARLY COMMUNICATION INTERVENTION}

The findings are presented in accordance with the framework presented in Figure 1, namely; the community nurses' discipline-specific; common and specialized knowledge and attitudes regarding ECI. Specialized knowledge and attitudes are presented according to the nurses' four roles in ECI, namely; screening, identification, referral and monitoring.

\section{Community Nurses'Discipline-Specific Knowledge for Early Communication Intervention}

Results indicate that the training programme did influence the community nurses' discipline-specific knowledge with respect to ECI. ANOVA analysis was significant at the 0.01 level, while post-hoc comparisons found that the means for Questionnaire 1 and 2 differed significantly. Table 3 reveals that before training, the majority of the nurses

TABLE 3: Community nurses' level of confidence in their discipline-specific knowledge areas as evident in the pre- and post-training surveys

\begin{tabular}{|c|c|c|c|c|c|c|c|c|c|}
\hline \multirow[t]{2}{*}{ KNOWLEDGE AREA } & \multicolumn{3}{|c|}{$\begin{array}{c}\text { NOT CONFIDENT } \\
\%\end{array}$} & \multicolumn{3}{|c|}{$\begin{array}{l}\text { MODERATELY } \\
\text { CONFIDENT \% }\end{array}$} & \multicolumn{3}{|c|}{$\begin{array}{l}\text { CONFIDENT } \\
\%\end{array}$} \\
\hline & Q1 & Q2 & Q3 & Q1 & Q2 & Q3 & Q1 & Q2 & Q3 \\
\hline 1. Normal infant development & 4.2 & 0 & 4.8 & 25 & 8.3 & 23.8 & 70.8 & 91.7 & 71.4 \\
\hline 2. Atypical infant development & 16.7 & 0 & 4.8 & 58 & 25 & 42.9 & 25 & 75 & 52.4 \\
\hline 3. Family functioning and assessment & 4.2 & 0 & 9.5 & 54.2 & 29.2 & 38.1 & 41.7 & 70.8 & 52.4 \\
\hline 4. Assessment of infants and toddlers & 16.7 & 4.2 & 0 & 41.7 & 33.3 & 33.3 & 41.7 & 62.5 & 66.7 \\
\hline $\begin{array}{l}\text { 5. Planning, implementing and } \\
\text { evaluating an intervention plan }\end{array}$ & 20.8 & 4.2 & 0 & 54.2 & 29.1 & 47.6 & 25 & 66.7 & 52.4 \\
\hline $\begin{array}{l}\text { 6. Knowledge of the community's } \\
\text { medical, social and financial resources }\end{array}$ & 25 & 0 & 9.5 & 37.5 & 4.2 & 28.6 & 37.5 & 95.8 & 61.9 \\
\hline
\end{tabular}

KEY: Q1 = Questionnaire 1 Q2 = Questionnaire 2 Q3 = Questionnaire 3 
expressed moderate levels of confidence in their disciplinespecific knowledge, especially in the areas relating to atypical infant development, family functioning and family assessment, and planning, implementing and evaluating an intervention plan. However, immediately after training a significantly large number of the nurses felt confident, while six weeks after the training programme, although most of the nurses still expressed confidence, a large number indicated moderate levels of confidence. It is concluded that overall, more nurses were moderately confident rather than confident in their discipline-specific knowledge base.

Community nurses' discipline-specific knowledge base represents the foundation from which they would develop a common early intervention knowledge base and a specialized ECI knowledge base (Hanson \& Brekken, 1991). Despite the positive trends, however, it is concerning that the pre-training survey found most of the nurses to be moderately confident rather than confident in their discipline-specific knowledge base. The nature of the nurses' pre-service education and training experiences may provide an explanation as Cox (1996) states that the compressed and streamlined nursing curricula and the shortage of suitably qualified teaching staff are possible factors that may impact on the quality of early intervention education at the pre-service level. Informal discussions with community nurses in Kwa-Zulu Natal revealed that their pre-service training was also compressed and streamlined to equip them with the broad-based knowledge and skills that they required as primary health care providers. It appears that the nurses possess an unsatisfactory level of discipline-specific knowledge for ECI, to facilitate their competent implementation of ECI at family health clinics.

\section{Community Nurses' Common Knowledge and Attitudes Regarding Early Intervention}

\section{Common Knowledge regarding Early Intervention:}

Table 4 indicates that the training programme did influence the nurses' common knowledge for early intervention, as the ANOVA analysis was statistically significant at the 0.05 level, and the Bonferroni test found Questionnaire 3 to be significant. The nurses presented with adequate levels of common knowledge with respect to the definition, efficacy, and principles of early intervention, on all three questionnaires, although training resulted in a slight increase in knowledge levels. The nurses' knowledge of international legislation increased significantly six weeks after training. Unfortunately, similar findings did not occur with respect to their knowledge of South African legislation, as inadequate knowledge levels were evident on all three evaluations.

It is important for community nurses to be knowledgeable about the four areas of early intervention, as this will play a significant role in influencing their attitudes toward ECI, as well as facilitate effective service delivery to at-risk children and their families (Brandt \& Magyary,

TABLE 4: Community nurses' common knowledge regarding early intervention as evident during the preand post-training phases

\begin{tabular}{|c|c|c|c|c|c|c|c|c|c|}
\hline \multirow[t]{2}{*}{ Knowledge area } & \multicolumn{3}{|c|}{$\%$ True } & \multicolumn{3}{|c|}{$\%$ Uncertain } & \multicolumn{3}{|c|}{$\%$ False } \\
\hline & Q1 & Q2 & Q3 & Q1 & Q2 & Q3 & Q1 & Q2 & Q3 \\
\hline $\begin{array}{l}\text { 1. Early intervention is a range of } \\
\text { health care services that is avail- } \\
\text { able to promote the well being of } \\
\text { families with infants and toddlers } \\
\text { who maybe at-rick for develop- } \\
\text { mental disabilities }\end{array}$ & 95.8 & 100 & 100 & 4.2 & 0 & 0 & 0 & 0 & 0 \\
\hline $\begin{array}{l}\text { 2. International laws do not autho- } \\
\text { rize the provision of early inter- } \\
\text { vention services to at-risk infants } \\
\text { and toddlers. }\end{array}$ & 4.2 & 33.3 & 4.8 & 41.7 & 8.3 & 9.5 & 54.2 & 58.3 & 85.7 \\
\hline $\begin{array}{l}\text { 3. South African health care laws } \\
\text { authorize the provision of early } \\
\text { intervention services to at-risk } \\
\text { infants and toddlers. }\end{array}$ & 87.5 & 62.5 & 61.9 & 8.3 & 4.2 & 4.8 & 4.2 & 33.3 & 33.3 \\
\hline $\begin{array}{l}\text { 4. Early identification and initiation } \\
\text { of intervention services for } \\
\text { developmentally delayed children } \\
\text { is not effective in reducing and/or } \\
\text { preventing later delay. }\end{array}$ & 0 & 0 & 0 & 8.3 & 4.2 & 0 & 91.7 & 95.8 & 100 \\
\hline $\begin{array}{l}\text { 5. Community-based, family-centered, } \\
\text { coordinated and comprehensive } \\
\text { services will promote effective } \\
\text { management of at-risk children }\end{array}$ & 95.8 & 100 & 100 & 4.2 & 0 & 0 & 0 & 0 & 0 \\
\hline
\end{tabular}

KEY: Q1 = QUESTIONNAIRE 1. Q2 = QUESTIONNAIRE 2. Q3 = QUESTIONNAIRE 3. 
1989). The community nurses' demonstration of an adequate common knowledge base with respect to three of the four areas on the pre-training survey, strongly suggests the possibility that the information is currently being provided in their discipline-specific training. This finding has relevance for the planning of ECI in-service training programmes for community nurses, as these areas may not need to be addressed in detail in future programmes (Delport, 1998). However, the nurses' limited knowledge regarding international and national legislation on early intervention makes it clear that the nurses' common knowledge base for early intervention is inadequate.

The nurses' response to the question regarding South African legislation on early intervention may be attributed to the government's legislation of free health care services for all children under six years of age (Department of Health, 1995). Be this as it may, however, specific and detailed policies with respect to the provision of early intervention services for the at-risk infant and toddler population as outlined by the international legislation relating to Public Law 99-457 (Rossetti, 1996), is lacking in South Africa. The latter is currently identified as a priority issue in the White Paper on Integrated National Disability Strategy (1997).

It is clear that the current assumption that the nurses possess this common knowledge is incorrect, and supports research findings that many health professionals receive poor educational preparation for their roles as early interven. tionists (Weitzner-Lin et al., 1994; Delport, 1998).

\section{Common Attitudes regarding Early Intervention:}

The training programme did not influence the nurses' common attitudes as the ANOVA analysis was not significant at the 0.05 level. The findings in Table 5 generally indicate that the nurses expressed positive attitudes toward using a team approach to service delivery in early intervention. Nonetheless, some of them appear to have reservations about the transdisciplinary concepts of role release and role expansion.

Community nurses' possession of a common attitude base will facilitate the development of a philosophy towards ECI that is shared by speech-language therapists and audiologists (Rossetti, 1996). The current finding indicates that the nurses commenced the training programme with a positive attitude toward team management. Similar findings were obtained in the recent South African studies by Louw and Weber (1997) and Delport (1998). Discussions with the South African nurses during the training programme revealed that they were adequately informed of the importance of teamwork during their pre-service training. They also indicated familiarity with the workings of the multidisciplinary and interdisciplinary team models, but not the transdisciplinary model. It is important to note that the transdisciplinary approach is a relatively recent model of team functioning that is discussed in the literature (Briggs, 1997), and this may account for the nurses' unfamiliarity with the model.

The nurses' reservations regarding the principles of role release and role expansion may indicate their fear of the loss of professional autonomy and the blurring of professional boundaries, as discussed by Briggs (1997). The need for the nurses to be informed of the benefits of transdisciplinary practice for ECI is clear, as the short duration of the current training programme may not have been sufficient in this regard.

TABLE 5: Community nurses' attitudes regarding teamwork in early intervention as evident during the preand post-training phases

\begin{tabular}{|l|c|c|c|c|c|c|c|c|c|}
\hline \multirow{2}{*}{$\begin{array}{l}\text { Attitudes toward } \\
\text { teamwork }\end{array}$} & \multicolumn{3}{|c|}{ \% True } & \multicolumn{3}{c|}{ \% Uncertain } & \multicolumn{3}{c|}{ \% False } \\
\cline { 2 - 9 } & Q1 & Q2 & Q3 & Q1 & Q2 & Q3 & Q1 & Q2 & Q3 \\
\hline $\begin{array}{l}\text { 1. A team approach to service deli- } \\
\text { very is important for effective } \\
\text { management of at-risk infants } \\
\text { and toddlers. }\end{array}$ & 100 & 100 & 100 & 0 & 0 & 0 & 0 & 0 & 0 \\
\hline $\begin{array}{l}\text { 2. Health care professionals should } \\
\text { be encouraged to share their } \\
\text { discipline-specific knowledge and } \\
\text { skills by training other health } \\
\text { care professionals. }\end{array}$ & 95.8 & 95.8 & 95.2 & 4.2 & 0 & 0 & 0 & 4.2 & 4.8 \\
\hline $\begin{array}{l}\text { 3. Health care professionals should } \\
\text { be encouraged to carry out the } \\
\text { roles and responsibilities of other } \\
\text { professionals, provided that they } \\
\text { are trained to do so. }\end{array}$ & 70.8 & 79.2 & 71.4 & 4.2 & 4.2 & 4.8 & 25 & 16.7 & 23.8 \\
\hline $\begin{array}{l}\text { 4. It is important for community } \\
\text { nurses and speech-language } \\
\text { therapists and audiologists to } \\
\text { consult each other about children } \\
\text { who are at-risk for developing } \\
\text { communication disorders. }\end{array}$ & 100 & 100 & 100 & 0 & 0 & 0 & 0 & 0 & 0 \\
\hline
\end{tabular}

KEY: Q1 = QUESTIONNAIRE 1. Q2 = QUESTIONNAIRE 2. Q3 = QUESTIONNAIRE 3. 
TABLE 6: Community nurses' specialized knowledge and attitudes regarding early communication intervention

\begin{tabular}{|c|c|c|}
\hline $\begin{array}{l}\text { Community } \\
\text { Nurses Roles } \\
\text { in ECI }\end{array}$ & $\begin{array}{l}\text { Specialized Knowledge } \\
\text { regarding ECI }\end{array}$ & $\begin{array}{l}\text { Specialized Attitudes } \\
\text { regarding ECI }\end{array}$ \\
\hline Screening & $\begin{array}{l}\text { Results per question: } \\
\text { D1: Table } 7 \text { reveals that the nurses' pre-training knowledge } \\
\text { regarding the importance of communication for overall } \\
\text { development of the child was limited. Increased knowledge } \\
\text { was evident after training. } \\
\text { D2: Pre-training knowledge was adequate as > } 90 \% \text { of the } \\
\text { nurses considered a communication problem to be a factor } \\
\text { that could influence the emotional, cognitive and social } \\
\text { development of a child } \\
\text { D4: Table } 8 \text { indicates that the nurses' pre-training } \\
\text { knowledge regarding the } 13 \text { risk factors was inadequate, } \\
\text { but improved after training - though not in all. } \\
\text { ANOVA: significant at } 0.01 \text { level } \\
\text { Bonferroni test: significant differences between means for } \\
\text { Questionnaires } 1 \text { and } 2 \text {, and Questionnaires } 1 \text { and } 3 \text {. } \\
\text { Conclusion: Training programme did influence community } \\
\text { nurses specialized knowledge for screening }\end{array}$ & $\begin{array}{l}\text { Results per question: } \\
\text { Before and after the training programme, } \\
\text { the nurses expressed positive attitudes } \\
\text { towards the assessment of commu- } \\
\text { nication skills (D3), and the reliability } \\
\text { and validity of the developmental scree- } \\
\text { ning assessment utilized at the clinics } \\
\text { (D5\&6). However, shifts in the nurses' } \\
\text { responses across the three conditions of } \\
\text { testing indicate some degree of confusion } \\
\text { regarding the reliability and validity of } \\
\text { the screening assessment. } \\
\text { ANOVA: not significant at } 0.05 \text { level } \\
\text { Conclusion:Training programme did not } \\
\text { influence the nurses'specialized attitudes } \\
\text { towards screening }\end{array}$ \\
\hline Identification & $\begin{array}{l}\text { D7: Pre-training knowledge was adequate with respect to } \\
\text { factors that adversely affect the results of a communication } \\
\text { assessment. A further improvement was noted after } \\
\text { training. } \\
\text { D8: The nurses were not confident about their knowledge } \\
\text { of the eligibility criteria that need to be applied when } \\
\text { identifying a child as being at-risk for developing a } \\
\text { communication disorder. Confidence levels increased } \\
\text { significantly after Questionnaire } 2 \text { ( } 70.8 \% \text { ), but decreased } \\
\text { to } 57.2 \% \text { on Questionnaire } 3 \\
\text { D9: Excellent pre-training knowledge of the symptoms of a } \\
\text { communication disorder } \\
\text { ANOvA: not significant at } 0.05 \text { level } \\
\text { Conclusion: Training programme did not influence the } \\
\text { nurses' specialized knowledge regarding the identification } \\
\text { of children at-risk for communication disorders. }\end{array}$ & \\
\hline $\begin{array}{l}\text { Referral and } \\
\text { Monitoring }\end{array}$ & $\begin{array}{l}\text { D10: The nurses displayed excellent knowledge in } 6 \text { of the } \\
7 \text { roles of the speech-language therapist and audiologist } \\
\text { before and after training. Knowledge regarding the } \\
\text { management of feeding problems appeared to be proble- } \\
\text { matic, even after training. } \\
\text { D13: Before and after training, the majority indicated that } \\
\text { they would refer at-risk children to the speech-language } \\
\text { therapist and audiologist } \\
\text { D15: Pre-training knowledge about the community's speech- } \\
\text { language therapy and audiology resources was poor, but } \\
\text { increased significantly after training. } \\
\text { D16: Pre-training confidence in the nurses' knowledge } \\
\text { regarding ECI was inadequate, but improved significantly } \\
\text { after training. } \\
\text { ANOVA: significant at } 0.01 \text { level } \\
\text { Bonferroni test: significant differences between the means } \\
\text { for Questionnaire } 1 \text { and } 3 \text { and Questionnaires } 1 \text { and } 2 \\
\text { Conclusion: Training programme did influence community } \\
\text { nurses' specialized knowledge for referral and monitoring }\end{array}$ & $\begin{array}{l}\text { D11: Pre- and post-training responses } \\
\text { supported their roles in ECI as identified } \\
\text { in the study - however, displayed some } \\
\text { confusion regarding the depth of the } \\
\text { assessment required } \\
\text { D12:Displayed positive attitudes toward } \\
\text { the early referral of at-risk children } \\
\text { before and after training } \\
\text { D14:Pre- and post-training responses } \\
\text { indicated positive attitudes, toward thè } \\
\text { beneficial effects of speech-language } \\
\text { therapy and audiology services for at-risk } \\
\text { children } \\
\text { D17: Overwhelming support for receiving } \\
\text { assistance from speech-language thera- } \\
\text { pists and audiologists in the form of in- } \\
\text { service training programmes } \\
\text { ANOvA: not significant at } 0.05 \text { level } \\
\text { Conclusion: Training programme did } \\
\text { not influence community nurses' spe- } \\
\text { cialized attitudes toward referral and } \\
\text { monitoring }\end{array}$ \\
\hline & $\begin{array}{l}\text { Overall Conclusion : The training programme did } \\
\text { influence community nurses' specialized knowledge } \\
\text { for ECI }\end{array}$ & $\begin{array}{l}\text { Overall Conclusion: The training pro- } \\
\text { gramme did not influence community } \\
\text { nurses'specialized attitudes toward ECI }\end{array}$ \\
\hline
\end{tabular}

KEY: ECI = EARLY COMMUNICATION INTERVENTION. D1-17: refer to questions in the questionnairés 
Community Nurses' Specialized Knowledge and Attitudes Regarding Early Communication Intervention

Table 6 provides a summary of the main findings of the nurses' specialized knowledge and attitudes for each of the four ECI roles described. Overall findings signify that the community nurses in this study did not appear to possess the specialized knowledge that is required to enable them to effectively execute their tasks in ECI. This finding, once again, supports current research literature which contends that many health professionals are inadequately prepared for their roles as early interventionists (Weitzner-Lin et al., 1994; Delport, 1998).

The nurses' responses to questions relating to screening are particularly concerning. The fact that a limited number of the nurses were aware of the pivotal role of communication for the early identification of at-risk children is significant. This finding implies that the nurses may not be paying sufficient attention to the communication domain during developmental screenings. Research findings by Rossetti (1996) clearly emphasize that despite the interdependence among the cognitive, communicative, social and motor domains of development; communication remains an extremely sensitive indicator of an infant's overall development. The nurses' positive responses to this question after the training programme illustrate the positive role that training can play in enhancing their knowledge.

The fact that the majority of the nurses displayed limited knowledge about risk factors that contribute to developmental pathology and specifically communication delay, is also significant. The nurses' inadequate knowledge regarding prematurity and low birth weight is especially important as the literature identifies the two as the most important high risk factors that contribute to developmental delay in general, and communication delay in particular (Rossetti, 1996). Similar findings regarding the nurses' limited awareness of the potential negative effects of low birth weight and feeding problems on communication

TABLE 7 Community nurses' knowledge regarding the significance of the communication domain, as reflected in the pre- and post-training surveys: (Question D1)

\begin{tabular}{|c|c|c|c|c|}
\hline $\begin{array}{l}\text { Significance of the Communication } \\
\text { Domain }\end{array}$ & $\begin{array}{c}\text { Delayed } \\
\text { cognitive } \\
\text { development }\end{array}$ & $\begin{array}{c}\text { Delayed } \\
\text { motor } \\
\text { development }\end{array}$ & $\begin{array}{c}\text { Delayed } \\
\text { communication } \\
\text { development }\end{array}$ & $\begin{array}{l}\text { Delayed } \\
\text { psycho-social } \\
\text { development }\end{array}$ \\
\hline \multicolumn{5}{|l|}{$\begin{array}{l}\text { A. The most common symptom of } \\
\text { developmental disability in children } \\
\text { under } 3 \text { years of age is ... }\end{array}$} \\
\hline Questionnaire 1 & $25 \%$ & $54.2 \%$ & $20.8 \%$ & $0 \%$ \\
\hline Questionnaire 2. & $0 \%$ & $0 \%$ & $95.8 \%$ & $4.2 \%$ \\
\hline \multirow[t]{2}{*}{ Questionnaire 3} & $9.5 \%$ & $4.8 \%$ & $85.7 \%$ & $0 \%$ \\
\hline & $\begin{array}{l}\text { Cognitive } \\
\text { Skill }\end{array}$ & $\begin{array}{l}\text { Motor } \\
\text { Skill }\end{array}$ & $\begin{array}{c}\text { Communication } \\
\text { Skill }\end{array}$ & $\begin{array}{c}\text { Psycho-Social } \\
\text { Skill }\end{array}$ \\
\hline \multicolumn{5}{|l|}{$\begin{array}{l}\text { B. The skill that has the highest } \\
\text { predictive correlation with a child's } \\
\text { later intelligence attainment and } \\
\text { school performance is ... }\end{array}$} \\
\hline Questionnaire 1 & $58.3 \%$ & $0 \%$ & $37.5 \%$ & $4.2 \%$ \\
\hline Questionnaire 2 & $4.2 \%$ & $0 \%$ & $91.7 \%$ & $4.2 \%$ \\
\hline Questionnaire 3 & $4.8 \%$ & $0 \%$ & $95.2 \%$ & $0 \%$ \\
\hline & $\begin{array}{l}\text { Cognitive } \\
\text { Skill }\end{array}$ & $\begin{array}{l}\text { Motor } \\
\text { Skill }\end{array}$ & $\begin{array}{c}\text { Communication } \\
\text { Skill }\end{array}$ & $\begin{array}{c}\text { Psycho-Social } \\
\text { Skill }\end{array}$ \\
\hline $\begin{array}{l}\text { C. The developmental domain that } \\
\text { consistently separates low-risk from } \\
\text { high-risk children is the ... }\end{array}$ & & & & \\
\hline Questionnaire 1 & $25 \%$ & $4.2 \%$ & $33.3 \%$ & $37.5 \%$ \\
\hline Questionnaire 2 & $8.3 \%$ & $0 \%$ & $87.5 \%$ & $4.2 \%$ \\
\hline Questionnaire 3 & $9.5 \%$ & $0 \%$ & $81 \%$ & $9.5 \%$ \\
\hline
\end{tabular}


development in infants, were found in the study by Louw and Weber (1997). It appears that generally, South African community nurses' knowledge with respect to the latter areas appears to be inadequate.

The nurses' inadequate pre-training knowledge regarding most of the risk factors that were specific to South Africa's third world, multicultural and multilingual context is also noteworthy. The nurses' generally negative responses implied that they were not supportive of the transactional model of infant development that is currently advocated in the literature (Rossetti, 1996). The positive effects of training are again evident in the nurses' post-training responses.

The training programme did not significantly influence the community nurses' specialized knowledge regarding the identification of infants and toddlers at-risk for communication disorders. The community nurses appeared to be well versed in identifying communication symptoms in at-risk children. This finding was also evident in the study by Louw and Weber (1997) and may consequently imply that information regarding the symptoms of communication disorders is currently provided by the nurses' discipline-specific training.

Despite the ANOVA results indicating that the nurses' specialized knowledge for identification of at-risk children appeared satisfactory, the fact that approximately $30 \%$ of the sample were not aware of the potential adverse effects of factors that could affect the reliability of assessment results, is significant. According to Iglesias and Quinn (1997), social and environmental factors could influence the reliability of assessments administered in infancy and childhood. In South Africa, the possibility of incorrect identification is great, as the nurses indicated during the training programme that one of the main problems experienced was that children were brought to the clinic by people who were not the primary caregiver. In addition, they stated that cultural and language differences between the children/caregivers and themselves hampered their implementation of the developmental screening assessments. Approximately $67 \%$ of the sample of nurses in this study were English first language speakers who did not share the language and culture of the majority Black population of South Africa (Pickering et al., 1998). Lynch and Hanson (1993) as well as Iglesias and Quinn (1997) assert that the ethnic, culture, and language discrepancies between service providers and families can have a significant effect on the delivery of effective ECI services.

The community nurses' inadequate specialized knowledge regarding the referral and monitoring of at-risk children serves to further support the need for relevant educational and training programmes. Although the nurses appeared to be knowledgeable about the role of the speechlanguage therapist and audiologist, many of them were not aware of the role played by the speech-language therapist and audiologist in the management of children's feeding problems. Once again, these findings concur with those of Louw and Weber (1997).

The nurses' generally limited levels of specialized knowledge regarding referral and monitoring is significant since many of them revealed prior to and after training, that referrals would also be made to other health professionals as well as the speech-language therapist and audiologist. A possible explanation for this finding could relate to the limited

TABLE 8 Community nurses' knowledge of risk factors for communication disorders : (Question D4)

\begin{tabular}{|l|c|c|c|c|c|c|c|c|c|}
\hline \multirow{2}{*}{ RISK FACTORS } & \multicolumn{3}{|c|}{ \% YES } & \multicolumn{3}{|c|}{ \% UNCERTAIN } & \multicolumn{3}{|c|}{$\%$ NO } \\
\cline { 2 - 12 } & Q1 & Q2 & Q3 & Q1 & Q2 & Q3 & Q1 & Q2 & Q3 \\
\hline 1. Prematurity & 66.7 & 91.7 & 90.5 & 8.3 & 0 & 0 & 25 & 8.3 & 9.5 \\
\hline 2. Low birth weight & 41.7 & 87.5 & 85.7 & 12.5 & 0 & 0 & 45.8 & 12.5 & 14.3 \\
\hline 3. Developmental motor delay & 58.3 & 91.7 & 90.5 & 12.5 & 0 & 0 & 29.2 & 8.3 & 9.5 \\
\hline 4. Syndromes & 100 & 95.8 & 100 & 0 & 0 & 0 & 0 & 4.2 & 0 \\
\hline 5. Anatomical defects & 87.5 & 91.7 & 95.2 & 4.2 & 4.2 & 0 & 8.3 & 4.2 & 4.8 \\
\hline 6. Feeding problems & 45.8 & 91.7 & 90.5 & 25 & 4.2 & 4.8 & 29.2 & 4.2 & 4.8 \\
\hline 7. Poor parent-child interaction & 100 & 100 & 100 & 0 & 0 & 0 & 0 & 0 & 0 \\
\hline 8. Hearing problems & 100 & 100 & 100 & 0 & 0 & 0 & 0 & 0 & 0 \\
\hline 9. Frequent hospitalization & 58.3 & 95.8 & 95.2 & 25 & 0 & 4.8 & 16.7 & 4.2 & 0 \\
\hline 10. The family's poor educational status & 33.3 & 83.3 & 81 & 12.5 & 0 & 0 & 54.2 & 16.7 & 19 \\
\hline 11: The family's poor socio-economic status & 37.5 & 87.5 & 81 & 8.3 & 0 & 0 & 54.2 & 12.5 & 19 \\
\hline 12. The family's cultural background & 37.5 & 87.5 & 76.2 & 12.5 & 0 & 0 & 50 & 12.5 & 23.8 \\
\hline 13. The family's language background & 45.8 & 87.5 & 71.4 & 20.8 & 0 & 0 & 33.3 & 12.5 & 28.6 \\
\hline
\end{tabular}

KEY: Q1 = QUESTIONNAIRE $1 \quad$ Q2 = QUESTIONNAIRE $2 \quad$ Q3 = QUESTIONNAIRE 3 
utilization of community-based practice by speech-langùage therapists and audiologists in South Africa (Uys \& Hugo, 1997). This situation would also possibly explain why the nurses have a poor knowledge of speech-language therapy and audiology resources in the community.

When interpreting the significant increase in the community nurses' specialized knowledge for ECI, it is important to note that these findings could be attributed to the possible effects of testing, experimenter bias, experimental mortality, and the formulation of questions in the questionnaire. With respect to the nurses' attitudes, the fact that they already possessed positive attitudes and beliefs about the outcome of ECI, even before training, is encouraging as it reflects the current strength of the nurses' positive attitudes toward ECI.

Finally, despite the positive findings relating to the nurses' attitudes, their responses to some of the questions are disturbing and consequently warrant further analysis and discussion. The perception that an infant's communication development can only be assessed after the child has said the first word (question D3 in Table 6), reflects that these nurses appear not to be aware of the concept of continuum of risk. According to this concept, the beginning point for delayed communication skills occurs much earlier than when the child fails to say the first word at approximately one year of age (Rossetti, 1996). Thus, the nurses' current incorrect perception could have a detrimental effect on the early identification of at-risk infants and toddlers.

The nurses' positive response toward receiving assistance from speech-language therapists and audiologists in the form of in-service training programmes is encouraging. Although their responses can be viewed as being socially appropriate (Rosnow \& Rosenthal, 1996) similar findings by Louw and Weber (1997) and Delport (1998), serve to confirm this result.

In summary, the nurses' positive attitudes and limited specialized knowledge base for ECI before training, augurs well for the development of collaborative partnerships with speech-language therapists and audiologists.

\section{COMMUNITY NURSES' EVALUATION OF THE IN- SERVICE TRAINING PROGRAMME}

With respect to objective two, all the nurses stated that the training programme had a positive effect on their knowledge and attitudes regarding ECI services. The nurses appeared to be satisfied with most areas of the content and structure utilized in this study, except for the presentation time. The majority preferred training programmes to be presented in the mornings rather than afternoons, and over one day, instead of two afternoons. The nurses' suggestions regarding suitable training methods is also noteworthy, as their preferences for the use of videos, case studies and onsite visits clearly demonstrate their need for methods that depict the real life context ( Bennet, Watson \& Raab, 1991).

In conclusion, the overall results of this study clearly reflect that the interdisciplinary in-service training programme did significantly influence the community nurses' knowledge but not their attitudes toward the early identification of at-risk infants and toddlers ( $0-3$ years).

\section{CONCLUSIONS AND IMPLICATIONS}

The main finding of this study supports the speech-language therapist and audiologist's use of interdisciplinary in-service training programmes to enhance the knowledge and attitudes of community nurses regarding ECI. Various implications arise with regard to the role of speech-language therapists and their education and training. However, the conclusions and implications are made cautiously in acknowledgement of the study's exploratory nature and the limitations there of (Leedy, 1993). In view of the importance of the research topic for ECI in South Africa, it seems reasonable to make some tentative recommendations based on the findings of this study.

\section{IMPLICATIONS FOR THE ROLES OF SPEECH. LANGUAGE THERAPISTS AND AUDIOLOGISTS IN THE DELIVERY OF EARLY COMMUNICATION INTERVENTION SERVICES IN SOUTH AFRICA}

The following implications are identified:

\section{Adoption of the Transdisciplinary Team Approach to Increase Accessibility to ECI}

It is recommended that speech-language therapists and audiologists adopt the transdisciplinary team approach as it facilitates the ability of early interventionists to collaborate, and thus provide community-based ECI services, as supported by the National Rehabilitation Policy (1997). The current study clearly demonstrated that by adopting the principles of role expansion and role release, speechlanguage therapists and audiologists are able to utilize interdisciplinary training programmes to improve community nurses' knowledge regarding early identification and appropriate referral of children who are at-risk for developing communication disorders. By expanding their roles from that of service provider to that of educator, speech-language therapists and audiologists become brokers of information (Rossetti, 1996). This role enables them to extend their services from the tertiary level of service delivery to that of the secondary and primary levels where at-risk children and families are located. Uys and Hugo (1997) and Delport (1998) emphasize the dire need for speech-language therapists and audiologists to take their services to the clients, rather than waiting for clients to come to the service.

\section{Collaboration: Implications for Recommended Practice in ECI}

Within the constraints of the limited number of qualified speech-language therapists and audiologists currently practising in South Africa, it is imperative that speechlanguage therapists and audiologists are proactive in determining appropriate ways of delivering ECI services at family health clinics. The community-based model of intervention proposed by Fair and Louw (1999) may be utilised to guide further research regarding the nature of ECI services that South African speech-language therapists and audiologists can provide at family health clinics in South Africa.

The significance of the concept of collaboration for the role of speech-language therapists and audiologists in ECI is evident, however, the current study reflects that the nature of the collaborative relationship appears to differ according to the purpose and people involved in the collaborative partnership. It is clear that speech-language therapists and audiologists need to be competent in 
developing collaborative relationships with personnel at different levels of the health care system. For example, with key personnel at national level for advocacy purposes, with administrators at management level to gain entry into the discipline specific health service, with health providers in the community, and finally, with families with at-risk children. It is essential that further research is conducted on the nature of the collaborative process that is suitable for the different types of collaborative partnerships in ECI. Pickering et al. (1998) emphasize the need for identifying professional competencies that transcend those of specific disabilities, and that include those related to interdisciplinary team work in the delivery of community-based service delivery.

\section{Marketing Speech-Language Therapy and Audiology Services}

In addressing the nurses' poor awareness of speechlanguage therapy and audiology services in the community, it is recommended that South African speech-language therapists and audiologists need to increase their role relating to the marketing of ECI services for at-risk children (Louw, 1997). A six step cross-disciplinary marketing approach devised by Fugate and Fugate (1996) provides an effective and efficient method of generating professional and public awareness about ECI services.

\section{Training of Speech-Language Therapists and Audio- logists}

The present insufficient numbers of qualified speechlanguage therapists and audiologists in South Africa clearly highlight the need for the training of more personnel to cope with the current and projected demand for ECI services (Pickering et al., 1998). In addressing this need, however, it is crucial that recruitment efforts are directed towards increasing the cultural and linguistic diversity of students that is reflective of those shared by the majority population in the country (Uys \& Hugo, 1997; Pickering et al., 1998).

IMPLICATION FOR THE EDUCATION AND TRAI. NING OF SOUTH AFRICAN SPEECH-LANGUAGE THERAPISTS AND AUDIOLOGISTS IN EARLY COMMUNICATION INTERVENTION

The provision of more indirect, consultative and collaborative services requires speech-language therapists and audiologists to be competent and skilled in areas that they may not have been adequately trained in, during their pre-service years (Weitzner-Lin et al., 1994). It is therefore important that these areas are identified and adequately addressed in education and training programmes.

\section{The Need for Further Training in the Development of Collaborative Partnerships and Implementation of Interdisciplinary Training Programmes}

During the implementation of this study, it became evident that in order for speech-language therapists and audiologists to be able to transform their roles and utilize an alternate model of intervention, they needed to be competent in two vital areas in which they traditionally received little training. These areas are, firstly; collaboration with other health care providers utilizing the principles of the transdisciplinary team model; and secondly, the planning and implementation of interdisciplinary in-service programmes for the education and training of other early intervention professionals.

In the implementation of services to at-risk children and their families, it is evident that speech-language therapists and audiologists require specialized attitudes, knowledge and skills that are not adequately provided during their pre-service training (Weitzner-Lin et al., 1994; Delport, 1998). Therefore, besides reinforcing the recommendations of Delport (1998) regarding the need for further training in the identified areas, it is also recommended that competencies and specific outcomes are clearly identified according to the guidelines of the National Qualifications Framework. This will serve to guide the development of an appropriate curriculum for undergraduate and continuing educational and training programmes.

\section{Planning Appropriate Training Programmes}

The findings of Weitzner-Lin et al. (1994) are important in the planning of appropriate training efforts, as they indicate that formal course work was not the method through which most speech-language therapists obtained their specialized knowledge base. This study recommended that workshops and in-service programmes needed to be structured around learning experiences that provided therapists with more hands-on experience with at-risk children and their families. The guidelines provided by Roberts et al., (1995) may be used in the development of programmes for speech-language therapists and audiologists' specialization in early intervention.

In conclusion, the results of the present exploratory study clearly demonstrate the suitability and potential of collaborative team initiatives in expanding the delivery of ECI services in contexts that are plagued with limited financial and human resources. What is evident is that collaborative enterprises present early interventionists, like speech-language therapists and audiologists and community nurses, with challenges that highlight the need for transformation in their respective roles and responsibilities toward the delivery of efficacious ECI services to the atrisk population. Future research efforts are required to assist early interventionists in this regard by ensuring that solutions proposed are theoretically grounded and practically feasible within the developing South African context.

\section{ACKNOWLEDGEMENTS}

This article is based on a thesis submitted to the University of Pretoria for the Masters Degree in Communication Pathology. Assistance is acknowledged from Professors Brenda Louw and Rene Hugo, as well as colleagues at the University of Durban-Westville, Harsha Karthard and Cyril Govender.

\section{REFERENCES}

A National Health Plan for South Africa. (April, 1994). Prepared by the ANC with the technical support of WHO and UNICEF. American Association of Colleges of Nursing. (1996). Interdisciplinary education and practice. Journal of Professional Nursing, 12, (2), 119-123.

American Speech-Language Hearing Association. (1989). Communication-based services for infants, toddlers, and their families. ASHA, May, 32-34. 
American Speech-Language-Hearing Association (1991). The prevention of communication disorders: Tutorial. ASHA, 33 (Suppl.6), 15-41

Bennet, T., Watson, A.L. \& Raab, M. (1995). Ensuring competence in early intervention personnel through personnel standards and high-quality training. In Blackman, J.A. (Ed.). Training and continuing education in early intervention (pp196-208). United States of America: Aspen Publishers, Inc.

Brandt, P.A. \& Magyary, D.L. (1989). Preparation of clinical nurse specialists for family-centred early intervention. Infants and Young Children, 1, (3), 51-62.

Briggs, M.H. (1993). Team Talk: Communication skills for early intervention teams. Journal of Childhood Communication Disorders, 15 , (1), 33-40.

Briggs, M.H. (1997). Building early intervention teams. Working together for children and families. Gaithersburg: Aspen Publishers, Inc.

Brink, H.I. (1996). Fundamentals of research methodology for health care professionals. Cape Town: Juta \& Co, Ltd.

Cox, A.W. (1996). Preparing nurses. In Bricker, D. \& Widerstrom, A. (Eds.). Preparing personnel to work with infants and young children and their families. A team approach (pp.161-179). Baltimore: Paul Brookes Publishing Co.

Delport, J. (1998). 'n Diensleweringsmodel van vroeë kommunikasie intervensie op die Suid-Afrikaanse platteland: Opleiding van verpleegkundiges oor die identifikasie van jong kinders (0-3 jaar) met ' $n$ hoërisiko vir kommunikasieprobleme. Unpublished masters thesis, University of Pretoria, South Africa.

Department of Health. (November, 1995). Towards a National Health System. Draft for discussion from the Deputy DirectorGeneral: Policy and Planning. Pretoria.

Fair, L. \& Louw, B. (1999). Early communication intervention within a community-based intervention model in South Africa. The South African Journal of Communication Disorders, 46, 13-23.

Fugate, D.l. \& Fugate, J.M. (1996). Putting the marketing plan to work: Practical suggestions for early intervention programs. Infants and Young Children, 8, (4), 70-79.

Hanson, M.J. \& Brekken, L.J. (1991). Early intervention personnel model and standards: An interdisciplinary fielddeveloped approach. Infants and Young Children, 4, (1), 5461.

Hugo, S.R. (1996). Open letter to all participants in the curriculum development programme National Inter-University Curriculum Meeting. University of Pretoria. South Africa.

Iglesias, A \& Quinn, R. (1997). Culture as a context for early intervention. In Thurman, S.K., Cornwell, J.R. \& Gottwald, S.R. (Eds.). Contexts of early intervention (pp 55-71). Baltimore: Paul Brookes Publishing Company.

Leedy, P.D. (1993). Practical research: Planning and design. New York: Macmillan Publishing Company.

Louw, B. (1997). Early communication intervention: Guidelines for speech-language therapists and audiologists. SASHLA: Ethics and Standards Committee.

Louw, B. \& Kritzinger, A. (1991). Infants with Down's Syndrome: Description of an early intervention approach. The South African Journal of Communication Disorders, 38, 25-31.

Louw, B. \& Weber, I. (1997). Attitudes and perceptions of nurses regarding early communication intervention. Health $S A$ Gesondheid, 2, (2), 16-22.

Lynch, E.W. \& Hanson, M.J. (1993). Changing demographics: Implications for training in early intervention. In Blackman, J.A. (1995). (Ed.). Training and continuing education in early intervention (pp. 209 - 217). United States of America: Aspen Publishers, Inc.

Moodley, L. (1999). An in-service training programme for community nurses in the identification of at-risk infants and toddlers. Unpublished masters thesis, University of Pretoria, South Africa.

National Health Plan for South Africa. (April, 1994). Prepared by the ANC with the technical support of WHO and UNICEF.

National Rehabilitation Policy. (December, 1997). Rehabilitation for all. Second Draft. Department of Health. South Africa.

Pickering, M., McAllister, L., Hagler, P., Whitehill, T.L., Penn, C., Robertson, S.J. \& McCready, V. (1998). External factors influencing the profession in six societies. American Journal of Speech-Language Pathology, 7, (4), 5-17.

Roberts, J.E., Crais, E., Layton, T., Watson, L. \& Reinhartsen, D. (1995). Developing an early intervention preservice specialization in speech-language pathology. American Journal of Speech Language Pathology, 4, (2), 31-36.

Rosnow, R.L. \& Rosenthal, R. (1996). Beginning behavioural research. A conceptual primer. New Jersey: Prentice-Hall, Inc.

Rossetti, L.M. (1993). Enhancing early intervention services to infants/toddlers and their families. Journal of Childhood Communication Disorders, 15, (1), 1-6.

Rossetti, L.M. (1996). Communication intervention. Birth to three. San Diego: Singular Publishing Group, Inc.

Trivette, C.M., Dunst, C.J., Hamby, D.W. \& LaPointe, M.A. (1996) Key elements of empowerment and their implications for early intervention. Infant-Toddler Intervention. The Transdisciplinary Journal, 6, (1), 59-73.

Uys, I. \& Hugo, R. (1997). Speech-language pathology and audiology: Transformation in teaching, research and service delivery. Health SA Gesondheid, 2, (2), 23-29.

Weitzner-Lin, B., Chambers, D., \& Sierpierski, J. (1994). What specialized knowledge is needed to provide early intervention services in children's hospitals? Infant-Toddler Intervention. The Transdisciplinary Journal, 4, (2), 87-104.

White Paper on Integrated National Disability Strategy. (November, 1997). Office of the Deputy President, T.M. Mbeki. Rustica Press.

Winton, (1996). A model for supporting higher education faculty in their early intervention personnel preparation roles. Infants and Young Children, 8, (3), 56-67. 


\section{SODNDS TOO GOOD
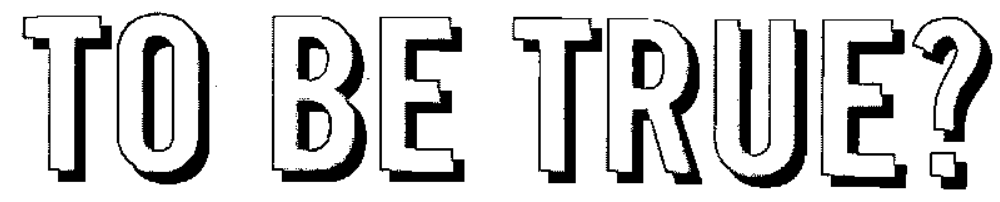

Swift

4 Low noise, low distortion sound

Easy to use

Quick and easy programming

High reliability

Cellphone compatible

Cost effective

\section{argo!}

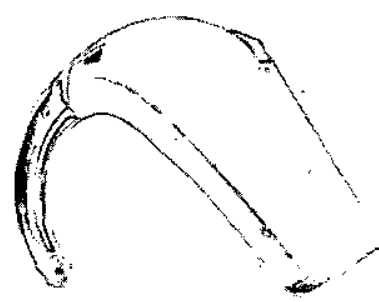

Excellent sound quality

Then hearing is believing. If you're not yet convinced that Oticon leads the way in programmable hearing instruments, we invite you to try the Ergo, Swift or Digilife.com range for yourself. Ergo redefines the fundamentals of hearing care

High reliability

Simple programming

New advanced

features while Swift and Digilife.com introduce a new concept in

Cellphone compatible

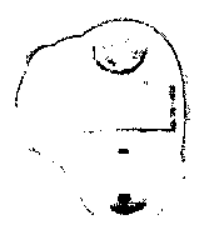

Cost effective affordable hearing care.

\section{digilife.com / Digifocus II}

Advanced digital technology

Virtually invisible

Interactive website benefits

Quick, easy hearing care options

Cost effective

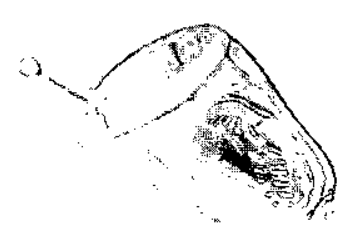

CELLPHONE COMPATIBLE!

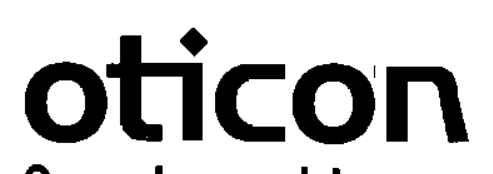

Sounds good to you

Toll Free 0800650750 or visit us at www.oticon.com and digilife.com 